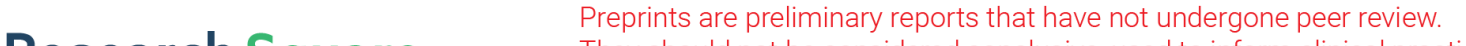 \\ They should not be considered conclusive, used to inform clinical practice, or referenced by the media as validated information. \\ Time scales for pluton growth, magma chamber formation and super-eruptions
}

Stephen Sparks ( $\nabla$ steve.sparks@bristol.ac.uk)

Bristol University

Marit van Zalinge

Bristol University

\section{Darren Mark}

Scottish Universities Environmental Research Centre

\section{Marissa Tremblay}

Purdue University https://orcid.org/0000-0001-9984-9554

\section{Brenhin Keller}

Dartmouth College

\section{Francis Cooper}

University of Bristol

\section{Alison Rust}

University of Bristol

\section{Physical Sciences - Article}

Keywords: silicic magma, super-eruptions, sanidine crystals

Posted Date: May 25th, 2021

DOI: https://doi.org/10.21203/rs.3.rs-447477/v1

License: (a) (i) This work is licensed under a Creative Commons Attribution 4.0 International License. Read Full License

Version of Record: A version of this preprint was published at Nature on August 3rd, 2022. See the published version at https://doi.org/10.1038/s41586-022-04921-9. 
1 Time scales for pluton growth, magma chamber formation and super-eruptions

2

3 M.E. van Zalinge ${ }^{1}$, D.F. Mark ${ }^{2,3}$, R.S.J. Sparks ${ }^{1}$, Tremblay, M.M. ${ }^{4}$, C.B. Keller ${ }^{5}$, F.J. Cooper ${ }^{1}$ and 4 A. Rust $^{1}$

5

1. School of Earth Sciences, University of Bristol, Wills Memorial Building, Bristol BS8 1RJ, United Kingdom.

2. Scottish Universities Environmental Research Centre, Rankine Avenue, Scottish Enterprise Technology Park, East Kilbride, G75 0QF, United Kingdom.

3. Department of Earth and Environmental Science, University of St Andrews, St Andrews, KY16 9AJ, UK

4. Department of Earth, Atmospheric and Planetary Sciences, 550 Stadium Mall Drive,

\section{Summary}

Generation of silicic magmas leads to emplacement of granite plutons, huge explosive volcanic eruptions and physical and chemical zoning of continental and arc crust ${ }^{1-7}$. While the time

20 scales for silicic magma generation in the deep and middle crust are prolonged ${ }^{8}$ magma

21 transfer into the upper crust followed by eruption is episodic and can be rapid ${ }^{9-12}$. Ages of

22 inherited zircons and sanidines from four Miocene ignimbrites in the Central Andes indicate a

23 gap of 4.6 Myr between the start of pluton emplacement and onset of super-eruptions, with

24 a 1 Myr cyclicity. Here we show that inherited sanidine crystals were stored at temperatures 
$<470^{\circ} \mathrm{C}$ prior to incorporation in the magma. Our observations are explained by silicic melt segregation in a middle crustal hot zone with episodic melt ascent from an unstable layer at the top of the zone with a time scale governed by the rheology of the upper crust. After thermal incubation of the growing batholith, large magma chambers formed in only a few thousand years or less by dyke transport from the hot zone melt layer. Instability and disruption of earlier plutonic rock occurred in a few decades or less just prior to or during super-eruptions.

Large-volume silicic ignimbrites are co-genetic with emplacement of large granitoid batholiths in the upper crust ${ }^{1-5}$. Ignimbrites provide snapshots in the evolution of batholith systems and contain information about pluton emplacement and silicic magma chamber formation from geochronology and crystal residence time studies ${ }^{6-11}$, complemented by numerical modelling ${ }^{12-17}$. Upper crustal silicic igneous systems are part of transcrustal magmatic systems in which differentiated (silicic) melts are generated in the middle and lower crust by reactive flow in mushes created by long-term influx of basalt ${ }^{8,18-21}$. Buoyancy instabilities ${ }^{8,22}$ within transcrustal magmatic systems drive differentiated magmas to shallow crustal levels, sometimes resulting in silicic volcanism.

The longevity of plutonic and related volcanic systems (typically $10^{6}$ to $10^{7}$ years) ) $^{1-7,17}$ contrasts with short timescales (typically $<10^{3}$ years) to assemble shallow magma chambers prior to large-magnitude ignimbrite eruptions ${ }^{9-11,23}$. Some crystals (antecrysts) entrained within erupting magmas are stored at temperatures near or even below the solidus for long periods of time prior to eruption ${ }^{24}$. These observations raise questions about silicic magma 
48 generation, plutons emplacement, magma chamber formation and how super-eruptions are

49 triggered.

50

51 We present new ${ }^{40} \mathrm{Ar} /{ }^{39} \mathrm{Ar}$ ages on tens of individual sanidine fragments sampled from early

52 Miocene rhyolitic ignimbrites located in northern Chile. These data are utilised along with ${ }^{206} \mathrm{~Pb} /{ }^{238} \mathrm{U}$ single crystal CA-ID-TIMS and laser-ablation ICP-MS zircon geochronology.

54 Terminology for magmatic systems is summarised in methods.

\section{Geological background}

57 The Oxaya Formation, located on the western slope of the Central Andes (Figure 1), comprises

58 four large volume (collectively $>2000 \mathrm{~km}^{3}$ ) regional ignimbrites ${ }^{25,26}$. Their ages are: 59 Poconchile $(22.626+0.0531 /-0.060 \mathrm{Ma})$; Cardones $(21.840+0.048 /-0.054 \mathrm{Ma})$; Molinos $(20.821+0.057 /-0.068 \mathrm{Ma})$ and Oxaya $(19.553+0.049 /-0.053 \mathrm{Ma})$. The ages are 95\% confidence interval including systematic uncertainties. Poconchile, Cardones and Oxaya ages were determined by applying a Bayesian model to integrate single-crystal zircon U-Pb ID-TIMS ${ }^{206} \mathrm{~Pb} /{ }^{238} \mathrm{U}$ analyses of the youngest crystals identified by LA-ICPMS screening ${ }^{25}$ and single crystal sanidine ${ }^{40} \mathrm{Ar} /{ }^{39} \mathrm{Ar}$ ages (methods). The ages (Figure 2 ) are modified from van Zalinge et al. ${ }^{25}$. The Molinos age is a new ${ }^{40} \mathrm{Ar} /{ }^{39} \mathrm{Ar}$ analysis of sanidine.

67 The Oxaya ignimbrites are rhyolites with mineral assemblages of plagioclase, quartz, biotite, FeTi oxides, \pm sanidine and \pm amphibole $e^{25,27}$ and ubiquitous accessory zircon. The Cardones

69 ignimbrite ${ }^{26}$ is crystal-rich (ca $30-40 \%$ ) and contains two petrologically distinct pumice varieties, one with high sanidine content but no amphibole and the other with low or no sanidine and minor amphibole. Magma temperatures are estimated ${ }^{27}$ in the range $850-750^{\circ} \mathrm{C}$ 
72 for the sanidine-poor magma and $770-670^{\circ} \mathrm{C}$ for the sanidine-rich magma. Barometry and

thermometry, together with rare earth element data, indicate generation of the silicic magmas by differentiation from wet basaltic to andesitic magmas with temperatures of 950$850^{\circ} \mathrm{C}$ emplaced in the middle and lower crust at depths of approximately $15 \mathrm{~km}$ or more. Isotopic data indicate assimilation of older $\mathrm{crust}^{28}$. The silicic magmas were emplaced into the upper crust at estimated depths from 6.0 to $8.7 \pm 2.0 \mathrm{~km}^{27}$.

\section{Geochronology of sanidines and inherited zircons}

Single-fragment ${ }^{40} \mathrm{Ar} /{ }^{39} \mathrm{Ar}$ total fusion ages of sanidine and ID-TIMS U-Pb crystallization ages of inherited zircons reveal highly dispersed age spectra for each ignimbrite, with single-crystal ages extending back millions of years prior to eruption (Figure 2). While widely documented in zircon ${ }^{29-31}$, age heterogeneity is now being recognized in erupted sanidine ${ }^{32,33}$. The zircons crystallization ages for Oxaya, Molinos and Cardones extend back millions of years to ages significantly older than apparent ${ }^{40} \mathrm{Ar} /{ }^{39} \mathrm{Ar}$ ages of sanidines. The time intervals between oldest observed LA-ICPMS spot age and eruption age for each sample are: Cardones (4.2 my); Molinos (3.5 my); and Oxaya (3.5 my).

The inherited sanidines and zircons indicate a magmatic history extending over 7.7 My between 27.3 Ma and 19.6 Ma for eruption of the youngest ignimbrite. The magma system developed at least 4.6 My prior to the first major ignimbrite. We can exclude significant silicic volcanism in the period 27.3 to $22.7 \mathrm{Ma}$ from observations of lithologies and detrital zircon ages in the late Oligocene to early Miocene Azapa Formation beneath the Oxaya Formation. Volcanic clasts in the Azapa Formation are intermediate ${ }^{34}$ while only 1 out of 149 detrital zircons $^{35}$ falls in the 27.3-22.7 Ma period. 
97 The repose intervals (Figure S2) between the ignimbrite eruptions are calculated as: 0.804 $98+0.065 /-0.073 \mathrm{Ma}$ for Poconchile-Cardones; 1.022 +0.078/-0.073 Ma for Cardones-Molinos; and 1.281 +0.074/-0.082 Ma for Molinos-Oxaca. Three ignimbrites (Poconchile, Cardones and Oxaya) indicate continuous zircon crystallization between the oldest age and eruption. Data for Molinos suggest either a hiatus in zircon crystallization over a 1 My period prior to eruption or that the Molinos magma body did not incorporate zircons from this period. The inherited sanidine are qualitatively consistent with the magmatic history implied by the inherited zircons but exhibit a younger and narrower age spread. The percentage of sanidine crystals in each sample that are older than the eruption ages are calculated as: Poconchile (64\%); Cardones (60\%); Molinos (38\%); and Oxaya (45\%).

Inherited sanidines and zircons date back to the early Oligocene (ca. $27 \mathrm{Ma}$ ), coinciding with an increase in convergence rate of 6 to $15 \mathrm{~cm} /$ year in the period 30 to 25 Ma between the Nazca and South American Plate ${ }^{36}$. This acceleration is associated with transition from flat slab to steeper subduction ${ }^{36}$ and onset of large-volume ignimbrite volcanism ${ }^{36-39}$.

\section{Interpretation of inherited sanidine data}

114 The ${ }^{40} \mathrm{Ar} /{ }^{39} \mathrm{Ar}$ ages older than eruption ages may have been modified by mixing or diffusion.

115 Sanidine crystals are commonly zoned ${ }^{27}$, so the Ar isotopic composition could be a mixture of old crystals and young (eruption age) parts of the crystal resulting in an intermediate age. In

117 between crystallization and eruption, radiogenic ${ }^{40} \mathrm{Ar}$ production will be countered by diffusion, which depends exponentially on temperature ${ }^{40}$. We modelled variation of apparent 
constrain storage temperatures. Diffusive loss of ${ }^{40} \mathrm{Ar}$ from sanidine will create rim-to-core

121 age gradients in individual crystals, with the oldest ages preserved in the crystal cores. Our analyses are typically of 0.5 to $1 \mathrm{~mm}$ fragments derived from much larger crystals up to 11 $\mathrm{mm}$ wide, so we calculated the ages of crystal centres.

Model results (Figure 3a) indicate that ages several Ma older than the eruption age can be preserved in crystal cores if the sanidines are stored at temperatures below $\sim 470^{\circ} \mathrm{C}$, with the oldest sanidines remaining below $400^{\circ} \mathrm{C}$. Previously the concept of cold storage based on zircon geochemistry and geochronology has inferred temperatures at or just below the solidus of rhyolitic magmatic systems $\left(\sim 700^{\circ} \mathrm{C}\right)^{23}$. Our results show that cold storage can occur at temperatures well below the solidus, as also deduced by Andersen et al. ${ }^{33}$ from the presence of old sanidines in the Bishop Tuff.

Preservation of old ages indicates magma residence times that are very short because diffusion of ${ }^{40} \mathrm{Ar}$ is fast at magmatic temperatures. We calculated the apparent age of sanidine crystal cores as a function of grain size for temperatures of $700^{\circ} \mathrm{C}$ and $770^{\circ} \mathrm{C}^{27}$, assuming no prior diffusive ${ }^{40} \mathrm{Ar}$ loss during cold storage. The results (Figure $3 \mathrm{~b}$ ) indicate that to preserve

137 the range of observed sanidine ages the residence times must be in the range of years to centuries. For example, for an original grain diameter of $11 \mathrm{~mm}$, ages older than $26 \mathrm{Ma}$ can

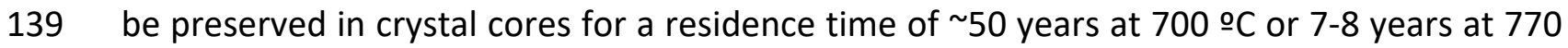

140 oC). These residence times agree with estimates of annual to decadal timescales for

141 incorporation of inherited crystals into an eruptible magma body and eruption ${ }^{8-10,23,24}$. Some

142 diffusive loss of ${ }^{40} \mathrm{Ar}$ during cold storage and subsequent residence in the magma can explain

143 why the age range of the zircons extends to greater ages than the sanidines. 
145 Sanidine crystals may also experience diffusive loss during welding and cooling of ignimbrite.

146 Pumice fiamme were sampled from welded units (Oxaya and Cardones) thick enough to make

147 this a concern. A temperature of $600^{\circ} \mathrm{C}$ and cooling time of 650 years at $200 \mathrm{~m}$ depth were

148 estimated for the Cardones ignimbrite ${ }^{41}$. We display calculations of time scales needed to

149 avoid diffusive loss in Figure 3c. For original crystal diameters of $11 \mathrm{~mm}$, ages older than 26

150 Ma can be preserved in the core for $\sim 10^{3}$ years at $600 \stackrel{\circ}{ } \mathrm{C}$. Minor losses of ${ }^{40} \mathrm{Ar}$ are therefore

151 likely, but are not enough to eradicate the old signatures.

152

\section{Discussion}

154 A conceptual model of magma generation, magma transport and magma chamber formation

155 (Figure 4) builds on emerging ideas of the dynamics and evolution of transcrustal magma systems ${ }^{8,19,21}$. Here silicic melt generated by reactive flow segregates continuously and slowly within a growing middle crustal hot zone constructed by incremental intrusion of mafic magma $^{21}$. A layer of buoyant silicic melt accumulates at the top of the hot zone. Rayleigh Taylor instabilities develop ${ }^{22}$ that eventually trigger rapid ascent of large volumes of magma into the upper crust, resulting in granite pluton growth, magma chamber formation and sometimes eruption.

163 The Oxaya magmatic system lasted at least 7.7 My, a time comparable to major episodes of batholith intrusion and development of large caldera systems ${ }^{1-7,17}$. Zircon ages are robust to

165 thermal disturbance, so indicate almost continuous silicic magma generation and crystallization. The magmatic system history involved an initial stage of $\sim 4.6$ My of pluton 
growth and a second stage ( $3.1 \mathrm{My}$ ) characterised by episodic large-scale ignimbrite eruptions.

170 We interpret the first stage as the incubation period predicted from thermal models of

171 incremental pluton growth ${ }^{13-15,17}$. Incubation time is defined as the time for the upper crustal

172 magma reservoir to generate a region with a melt fraction exceeding $0.4^{14}$. During this stage

173 silicic magma is transferred from the middle crust (depths $\geq 15 \mathrm{~km}$ ) to the upper crust (depths

$174 \sim 5$ to $8 \mathrm{~km})^{27}$. From Annen et al. ${ }^{15}$ using their equation 7 we estimate an upper limit for

175 magma reservoir growth of $3.5 \mathrm{~mm} /$ year over $4.6 \mathrm{My}$. We envisage pluton growth by

176 displacement of hot ductile crust downwards and sideways ${ }^{17}$ (Figure 4). In incremental

177 growth models each increment of magma cools and crystallizes quickly while most of the 178 growing pluton remains at much lower temperature. Models ${ }^{13,42}$ of steady pluton growth

179 indicate that temperatures below $450^{\circ} \mathrm{C}$ can be sustained across the pluton for growth rates 180 of $<1 \mathrm{~cm} /$ year, explaining preservation of old sanidine ages. Lack of silicic volcanic clasts and 181 detrital zircons with early Miocene ages in the underlying Azapa sediments ${ }^{35}$ suggests that 182 the incubation stage involved only pluton emplacement.

184 A persistent magma chamber can develop at the end of the incubation period (Figure 4). 185 However, old sanidine crystals within Oxaya ignimbrites show that magma chamber 186 formation prior to the super-eruptions took place rapidly (decades to centuries) in a very 187 dynamic disruptive environment, indicating highly episodic magma ascent. Episodic 188 emplacement promotes formation of large ephemeral magma chambers ${ }^{42,43}$. 
We apply a model ${ }^{22}$ of episodic magma ascent due to Rayleigh Taylor instabilities in slowly

191 developing melt layers at the top of the middle crustal hot zone beneath a subsolidus upper crust with a viscosity $\mu_{c}$. We propose that repose periods between major ignimbrite are controlled by upper crust rheology. The width of the unstable melt layer, $\mathrm{D}$, determines the wavelength, as it is much less than the unconfined fastest growing wavelength (see methods). The time scale, $\tau$, for an instability to grow into a diapir is (see methods):

where $\Delta \rho$ is the density contrast $\left(\sim 300 \mathrm{~kg} / \mathrm{m}^{3}\right)$ between the melt layer and overlying crust. Choosing 1 Myr as the repose period and $D=40 \mathrm{~km}$ as a typical pluton width we calculate a crustal viscosity of $5 \times 10^{19} \mathrm{~Pa}$ s, which is consistent with experimental data ${ }^{43}$ at $500-700^{\circ} \mathrm{C}$.

We compared dyking and diapirism ${ }^{45,46}$ as mechanisms of magma transport (methods) and conclude only dyke transport is viable to enable rapid formation of upper crustal magma chambers. During RT instability at times comparable to that given by equation 1 conditions for dyke formation at the top of the incipient diapir are inferred to develop. We develop and justify (methods) a simple exchange flow model ${ }^{47}$ of crust with viscosity $\mu_{c}$ slowly subsiding over a large area and magma with viscosity $\mu_{m}$ ascending through a narrow cylindrical conduit as an approximation of dyke transport. Calculations of conduit radii, fluxes, magma chamber volume and assembly time are presented in Table 1 for $\Delta \rho=300 \mathrm{~kg} / \mathrm{m}^{3}, \mu_{\mathrm{m}}=10^{5} \mathrm{~Pa}$ s and $\mu_{\mathrm{c}}$ $=10^{19} \mathrm{~Pa} \mathrm{~s}$, considering transfer of magma through the conduit from a layer initially $1 \mathrm{~km}$ thick of radius $\mathrm{R}$. Three radius values for the collapsing cylindrical crust region are chosen at 15, 20 and $25 \mathrm{~km}$ to span the scale of large plutons and super-eruption caldera systems. Fluxes are 
large, explaining how large volume magma chambers can be assembled over periods of a few

215 thousand years.

217 Thermal models of episodic pluton growth and magma chamber formation ${ }^{13-15,17,42,43}$ are

218 consistent with the exchange flow model. Episodic magma ascent at rates much higher than

219 time averaged rates are needed to form large upper crustal magma chambers ${ }^{42}$ and are

220 illustrated by parametric models for the Jurassic Yerington batholith in Nevada ${ }^{43}$. The Luhr

221 Hill pluton has similar geochemical and mineralogical characteristics to the Oxaya ignimbrites.

222 Intrusion rates greater than about $10 \mathrm{~cm} /$ year were required to form a large shallow magma

223 chamber. For a cylindrical magma chamber with radius $20 \mathrm{~km}$ this translates into a flux of 0.12

$224 \mathrm{~km}^{3} /$ year or more. This estimate is comparable to the calculated exchange flow fluxes (Table

225 1) and about two orders of magnitude greater than the $0.001 \mathrm{~km}^{3} /$ year needed to generate $\sim 1000 \mathrm{~km}^{3}$ of magma in $1 \mathrm{Myr}$.

Finally we discuss incorporation of older crystals into the magmas. Studies of zircon age distributions led to the concept of long periods of cold storage and rapid mobilization of silicic magma into eruptible magma bodies ${ }^{23}$. However, preservation of old sanidines rules out cold storage within a non-eruptible mush system at or above the solidus ${ }^{24}$. Rather the observations indicate catastrophic assimilation and mixing of significant amounts of cold rock.

We propose that magma chamber plutonic roof rocks (Figure 4b) disintegrate and are mixed by convection just prior to and during eruption.

Data Availability

All data are provided as tables ED1 and ED2 in supplementary materials. 


\section{Code Availability}

241 Code for carrying out the argon diffusion calculations can be found

242 at https://github.com/Thermochronology-At-Purdue in the repository named Oxaya2021.

243 Code for the Bayesian modelling of the geochronological data is

244 in https://github.com/brenhinkeller/Chron.jl. (see reference 65). A file that contains both

245 the script and the data files in the csv format can be downloaded from

246 https://storage.googleapis.com/brenhin/OxayaArArUPb Chron.tgz

\section{References}

1. Lipman, P.W. Incremental assembly and prolonged consolidation of Cordilleran magma chambers: Evidence from the Southern Rocky Mountain volcanic field. Geosphere 3, 4270, (2007).

2. Glazner, A. F., Bartley, J. M., Coleman, D. S., Gray, W. \& Taylor, R. Z. Are plutons assembled over millions of years by amalgamation from small magma chambers? Geological Society of AmericaToday 14, 4-12 (2004).

3. Bachmann, O., Miller, C. \& De Silva, S. The volcanic-plutonic connection as a stage for understanding crustal magmatism. Journal of Volcanology and Geothermal Research 167, 1-23 (2007).

4. Frazer, R. E., Coleman, D. S. \& Mills, R. D. Zircon U-Pb geochronology of the Mount Givens Granodiorite: Implications for the genesis of large volumes of eruptible magma. Journal of Geophysical Research: Solid Earth 119, 2907-2924 (2014).

5. Lipman, P. W. \& Bachmann, O. Ignimbrites to batholiths: Integrating perspectives from geological, geophysical, and geochronological data. Geosphere, GES01091. 01091 (2015). 
6. Charlier, B.L.A., Wilson, C.J.N., Lowenstern, B., Blake, S., van Calsteren P.W. \& Davidson, J.P. Magma Generation at a Large, Hyperactive Silicic Volcano (Taupo, New Zealand) Revealed by U-Th and U-Pb Systematics in Zircons. J Petrology 46, 3-32 (2005)

7. de Silva, S.L. \& Gosnold, W.D. Episodic construction of batholiths: insights from the spatiotemporal development of an ignimbrite flare-up. Journal of Volcanology and

8. Sparks, R.S.J., Annen, C., Blundy, J.D., Cashman, K.V., Rust, A.C. \& Jackson, M.D. Formation and dynamics of magma reservoirs. Philosophical Transactions of the Royal Society A 377: 20180019 (2019).

9. Druitt, T.H., Costa, F., Deloule, E., Dungan, M. \& Scaillet, B. (2012). Decadal to monthly timescales of magma transfer and reservoir growth at a caldera volcano. Nature $482,77-$ 80 (2012).

10. Shamloo, H.I. \& Till, C.B. Decadal transition from quiescence to supereruption: petrologic investigation of the Lava Creek Tuff, Yellowstone Caldera. Contributions to Mineralogy and Petrology 174:32 (2019).

11. Pamukçu, A.S., Wright, K.A., Gualda, G.A.R. \& Gravley, D. Magma residence and eruption at the Taupo Volcanic Center (Taupo Volcanic Zone, New Zealand): insights from rhyolite-MELTS geobarometry, diffusion chronometry, and crystal textures. Contributions

12. Rubin, A.E., Kari M. Cooper, K.M., Till, C.B., Kent A.R.J., Costa F., Bose M. Gravley D., 
13. Annen, C., Scaillet, B. \& Sparks, R.S.J. Thermal constraints on the emplacement rate of a large intrusive complex: the Manaslu Leucogranite, Nepal Himalaya. Journal of Petrology 47, 71-95 (2006).

14. Annen, C. From plutons to magma chambers: thermal constraints on the accumulation of eruptible silicic magma in the upper crust. Earth and Planetary Science Letters 284, 409416 (2009).

15. Annen, C., Blundy, J. D., Leuthold, J. \& Sparks, R. S. J. Construction and evolution of igneous bodies: Towards an integrated perspective of crustal magmatism. Lithos 230, 206-221 (2015).

16. Gregg, P.M., de Silva, S.L., Grosfils, E.B. \& Parmigiani, J.P. Catastrophic caldera-forming eruptions: Thermomechanics and implications for eruption triggering and maximum caldera dimensions on Earth. Journal of Volcanology and Geothermal Research 241-242, 1-12 (2012).

17. Paterson, S., Okaya, D., Memeti, V., Economos, R. \& Miller R.B. Magma addition and flux calculations of incrementally constructed magma chambers in continental margin arcs: Combined field, geochronologic, and thermal modeling studies. Geosphere 7, 1439-1468 (2011).

18. Annen, C., Blundy, J.D. \& Sparks, R.S.J. The genesis of intermediate and silicic magmas in deep crustal hot zones. Journal of Petrology 47, 505-539 (2006).

19. Solano, J.M.S., Jackson, M.D., Sparks, R.S.J., Blundy, J.D. \& Annen, C. Segregation in Deep Crustal Hot Zones: a Mechanism for Chemical Differentiation, Crustal Assimilation and the Formation of Evolved Magmas. Journal of Petrology 53, 1999-2026 (2012). 
20. Cashman K.V., Sparks, R.S.J. \& Blundy J. Vertically extensive and unstable crystals mushes: a unifying view of igneous processes associated with volcanoes. Science 355, 6331 eaag3055 (2017).

21. Jackson, M. Blundy J. \& Sparks R.S.J. Chemical differentiation, cold storage and remobilization of magma in the Earth's crust. Nature 564, 405-409 (2018).

22. Seropian, G., Rust, A. \& Sparks, R.S.J. The gravitational stability of lenses in magma mushes: confined Rayleigh-Taylor instabilities. Journal of Geophysical Research 123, 3593-3607 (2017).

23. Cashman, K.V. \& Giordano, G. Calderas and magma reservoirs. Journal of Volcanology and Geothermal Research 288, 28-45 (2014).

24. Cooper. K.M. \& Kent, A.J.R. 2014, Rapid remobilization of magmatic crystals kept in cold storage. Nature 506, 480-483 (2014).

25. van Zalinge, M.E., Sparks, R.S.J., Cooper, F.J. \& Condon, D. Early Miocene large volume ignimbrites of the Oxaya Formation, Central Andes. Journal of the Geological Society of London 173, 716-733 (2016).

26. García, M., Gardeweg, M., Clavero, J. \& Hérail, G. 2004. Arica map: Tarapacá Region, scale 1:250,000. In: CartaGeológica de Chile SerieGeología básica, 84, Servicio Nacional de Geología y Minería, Santiago.

27. van Zalinge, M.E., Sparks, R.S.J. \& Blundy, J.D. Petrogenesis of the large-volume Cardones ignimbrite, Chile; development and destabilisation of a complex magma-mush system. Journal of Petrology 58, 1975- 2006 (2018). 
28. Freymuth, H., Brandmeier, M. \& Wörner, G. The origin and crust/mantle mass balance of Central Andean ignimbrite magmatism constrained by oxygen and strontium isotopes and erupted volumes. Contributions to Mineralogy and Petrology 169, 1-24 (2015).

29. Lissenberg, C. J., Rioux, M., Shimizu, N., Bowring, S. A. \& Mével, C. Zircon Dating of Oceanic Crustal Accretion. Science 323, 1048-1050 (2009).

30. Wotzlaw, J.-F. et al. Tracking the evolution of large-volume silicic magma reservoirs from assembly to supereruption. Geology 41, 867-870 (2013).

31. Samperton, K. M., Bell, E. A., Barboni, M., Keller, C. B. \& Schoene, B. Zircon agetemperature-compositional spectra in plutonic rocks. Geology 45, 983-986 (2017).

32. Ellis, B. S. et al. Split-grain ${ }^{40} \mathrm{Ar} /{ }^{39} \mathrm{Ar}$ dating: Integrating temporal and geochemical data from crystal cargoes. Chemical Geology 457, 15-23 (2017).

33. Andersen, N.L., Jicha, B.R., Singer, B.S. \& Hildreth, W. Incremental heating of Bishop Tuff sanidine reveals pre-eruptive radiogenic Ar and rapid remobilization from cold storage PNAS 114 (47) 12407-12412 (2017).

34. Pinto. L., Hérail, G., Fontan, F. \& Parseval, P. Neogene erosion and uplift of the western edge of the Andean Plateau as determined by detrital heavy mineral analysis. Sedimentary Geology 195, 217-237 (2007).

35. Wotzlaw, J.F., Decou, A., von Eynatten, H., Worner, G. \& Frei, D. Jurassic to Palaeogene tectono-magmatic evolution of northern Chile and adjacent Bolivia from detrital zircon U$\mathrm{Pb}$ geochronology and heavy mineral provenance. Terra Nova 23, 399-406 (2011) 
36. Somoza, R. Updated azca (Farallon)-South America relative motions during the last 40 My: implications for mountain building in the central Andean region. Journal of South American Earth Sciences 11, 211-215 (1998).

37. Isacks, B. L. Uplift of the central Andean plateau and bending of the Bolivian orocline. Journal of Geophysical Research: Solid Earth 93, 3211-3231 (1988).

38. Lamb, S. \& Hoke, L. Origin of the high plateau in the Central Andes, Bolivia, South America. Tectonics 16, 623-649 (1997).

39. Kay, S. M. \& Coira, B. L. Shallowing and steepening subduction zones, continental lithospheric loss, magmatism, and crustal flow under the Central Andean Altiplano-Puna Plateau. Geological Society of America Memoirs 204, 229-259 (2009).

40. Hora, J. M., Singer, B. S., Jicha, B. R., Beard, B. L., Johnson, C. M., de Silva, S. \& Salisbury, M. Volcanic biotite-sanidine ${ }^{40} \mathrm{Ar} /{ }^{39} \mathrm{Ar}$ age discordances reflect $\mathrm{Ar}$ partitioning and preeruption closure in biotite. Geology 38, 923-926 (2010).

41. Platzman, E.S., Sparks, R.S.J. \& Cooper, F.J. Fabrics, facies and flow through a large-volume ignimbrite: Pampa De Oxaya, Chile. Bulletin of Volcanology 82:8 (2020).

42. Schöpa, A. \& Annen, C. The effects of magma flux variations on the formation and lifetime of large silicic magma chambers. Journal of Geophysical Research: Solid Earth 118, 926942 (2013).

43. Schöpa A., Annen, C., Dilles, J.H., Sparks R.S.J. \& Blundy, J.D. Magma Emplacement Rates and Porphyry Copper Deposits: Thermal Modeling of the Yerington Batholith. Economic Geology 112, 1653-1672 (2018). 
382

383 Table 1. Results of calculations for exchange flow. Calculations are shown for the flow up a

44. Burgmann, R. \& Dresen, G. Rheology of the Lower Crust and Upper Mantle: Evidence from Rock Mechanics, Geodesy, and Field Observations. Annual Reviews of Earth \& Planetary Sciences 36, 531-567 (2008).

45. Burov, E., Jaupart, C. \& Guillou-Frottier, L. Ascent and emplacement of buoyant magma bodies in brittle-ductile upper crust. Journal of Geophysical Research: Solid Earth, 108(B4) (2003).

46. Petford, N., Cruden, A.R., McCaffrey, K.J.W. \& Vigneresse, J.L. Granite magma formation, transport and emplacement in the Earth's crust. Nature 408, 669-673 (2000).

47. Suckale, J., Qin, Z., Picchi, D., Keller, T., \& Battiato, I. (2018). Bistability of buoyancy-driven exchange flows in vertical tubes. Journal of Fluid Mechanics, 850, 525-550.

\begin{tabular}{|l|l|l|l|l|}
\hline $\begin{array}{l}\text { Crustal radius } \\
(\mathrm{km})\end{array}$ & $\begin{array}{l}\text { Conduit radius } \\
(\mathrm{m})\end{array}$ & $\begin{array}{l}\text { Magma flux } \\
\left(\mathrm{km}^{3} / \mathrm{yr}\right)\end{array}$ & $\begin{array}{l}\text { Magma volume } \\
\left(\mathrm{km}^{3}\right)\end{array}$ & $\begin{array}{l}\text { Assembly time } \\
(\text { years })\end{array}$ \\
\hline 15 & 4.7 & 0.18 & 710 & 3800 \\
\hline 20 & 6.3 & 0.58 & 1300 & 2200 \\
\hline 25 & 7.9 & 1.40 & 2000 & 1400 \\
\hline
\end{tabular}

384 cylindrical conduit and are rounded to 2 significant figures. Results are shown for conduit 385 radius, magma flux, magma chamber volume and magma chamber assembly times for a melt 
386 layer $1 \mathrm{~km}$ thick with crustal viscosity $\mu_{\mathrm{c}}=10^{19} \mathrm{~Pa} \mathrm{~s}$. Calculations for three different radius 387 values of the magma system (See Figure 4) are presented.

388 

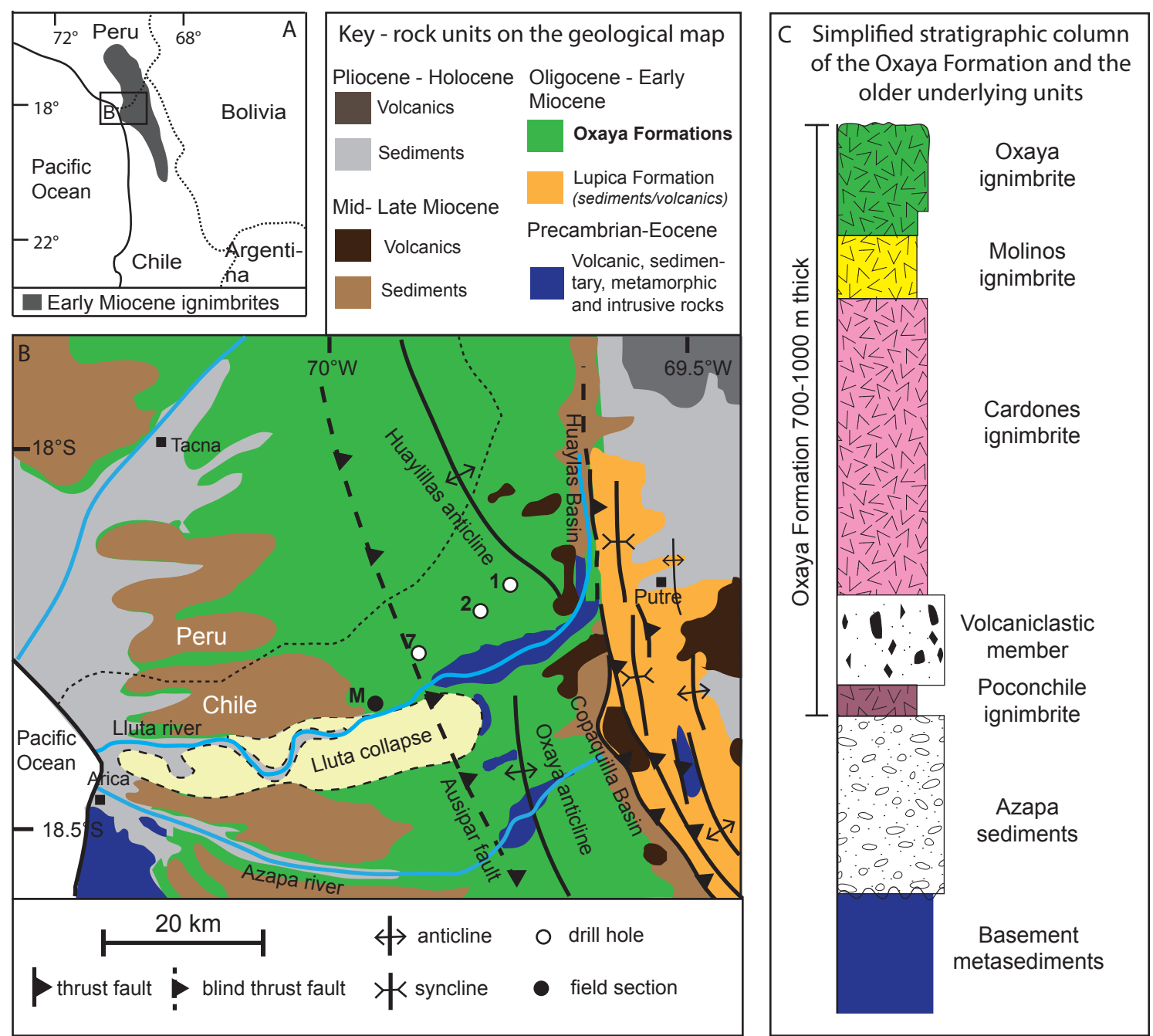

391

392 Figure 1. (A) Location of study area in Central Andes with distribution of early Miocene

393 ignimbrites. (B) Simplified geological map of study area showing distribution of the Oxaya

394 Formation and major structural features in the area modified by van Zalinge et al. ${ }^{25}$ after

395 Garcia et al. $^{26}$ (C) Simplified stratigraphy ${ }^{24}$ of the Oxaya Formation and underlying stratigraphic units based on locality $\mathrm{M}$ and drill hole data (B). 

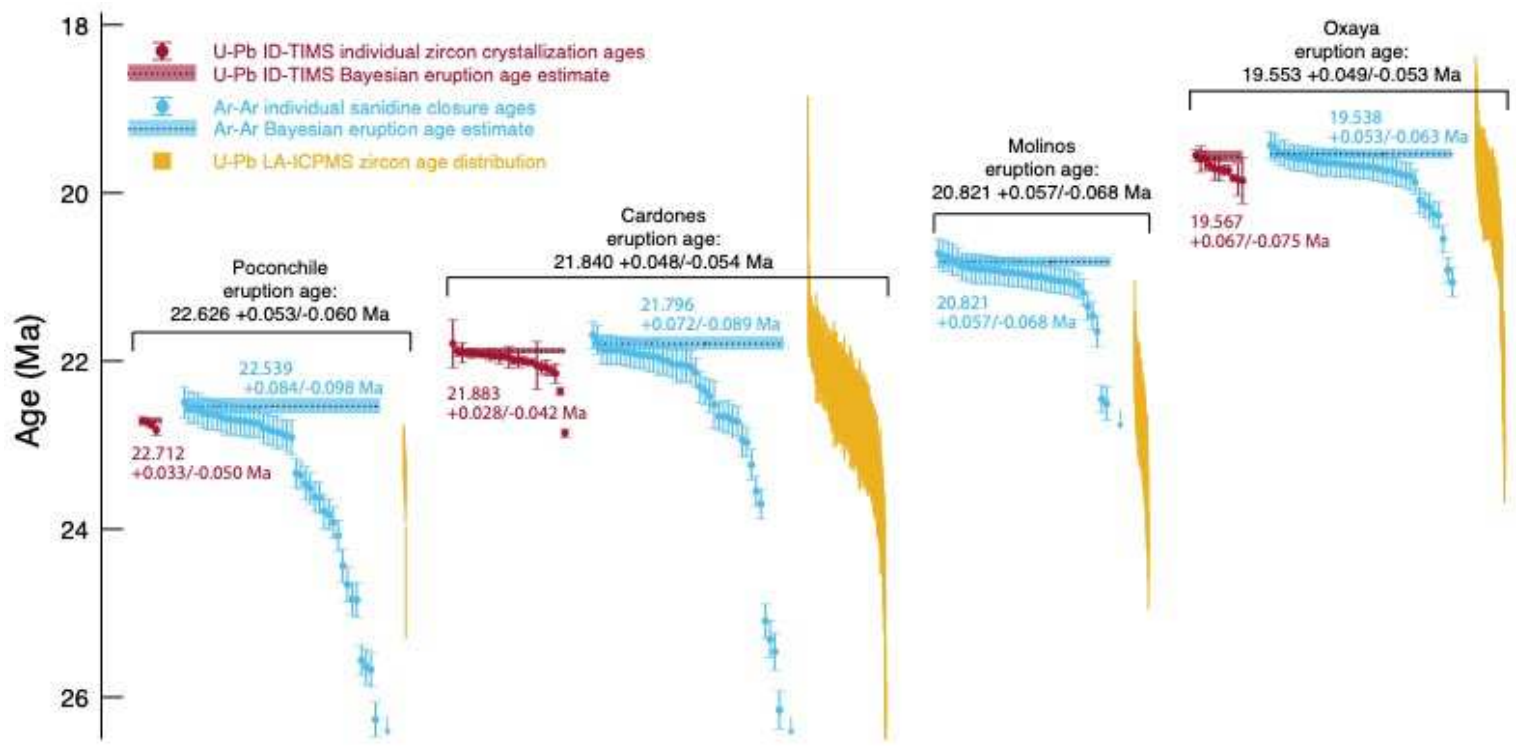

404 Figure 2. Geochronological data for the four ignimbrites of the Oxaya Formation. Four kinds sanidine fragments; and U-Pb ages (LA-ICPMS) of individual inherited zircons. The fourth preferred age comes about from integration of the U-Pb ages of zircons and $\mathrm{Ar} / \mathrm{Ar}$ ages of sanidines. The data are ordered by age from left (youngest) to right (oldest). The error bars on data points are 2 standard deviation values.

410

411 

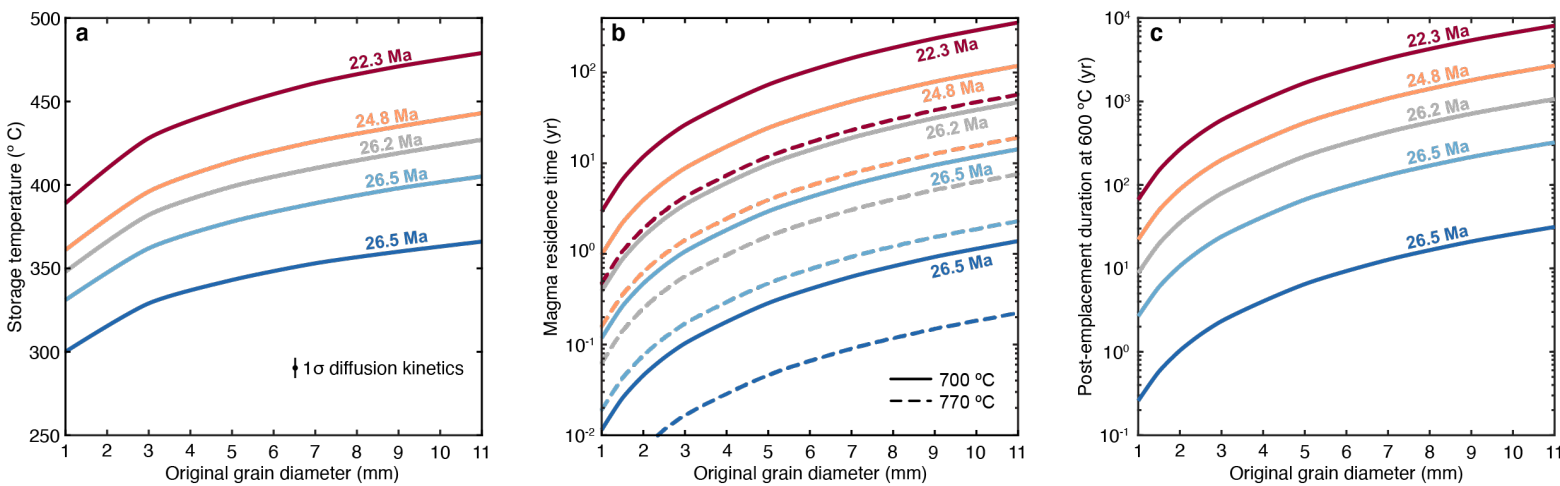

Figure 3. Models of the effects of (A) storage temperatures, (B) magma residence times, and

(C) post-emplacement welding and cooling of the ignimbrites on sanidine ${ }^{40} \mathrm{Ar} /{ }^{39} \mathrm{Ar}$ ages in

417 the cores of sanidine crystals. We show model ages for the cores of crystals, where the core

418 is defined as a the volume at the center of the original crystal that has a diameter that is $50 \%$

419 that of the original crystal. We show ${ }^{40} \mathrm{Ar} /{ }^{39} \mathrm{Ar}$ ages of crystal cores for two reasons. First, we

420 know that the ${ }^{40} \mathrm{Ar} /{ }^{39} \mathrm{Ar}$ measurements were made on sanidine crystal fragments, and that

421 the grains were fragmented during the mineral separation process. Second, diffusive loss of

$422{ }^{40} \mathrm{Ar}$ will cause rim-to-core age gradients; therefore it is the crystal cores that will provide the 423 oldest ages in our observed ${ }^{40} \mathrm{Ar} /{ }^{39} \mathrm{Ar}$ age distributions. For each set of models, we assume

424 that all sanidines crystallized at 26.5 Ma and that eruption occurred at 21.8 Ma. (A) Modeled sanidine crystal core ${ }^{40} \mathrm{Ar} /{ }^{39} \mathrm{Ar}$ age as a function of original grain size and storage temperature.

(B) Modeled sanidine crystal core ${ }^{40} \mathrm{Ar} /{ }^{39} \mathrm{Ar}$ age as a function of original grain size and magma residence time, assuming that no diffusive ${ }^{40} \mathrm{Ar}$ loss occurred prior to magma entrainment. Models are shown for two magma temperatures - 700 and 770 드, based on geothermometry ${ }^{26}$. (C) Modelled sanidine crystal core ${ }^{40} \mathrm{Ar} /{ }^{39} \mathrm{Ar}$ age at $600^{\circ} \mathrm{C}$, the maximum prior diffusive ${ }^{40} \mathrm{Ar}$ loss during pre-eruption storage or magma residence. 

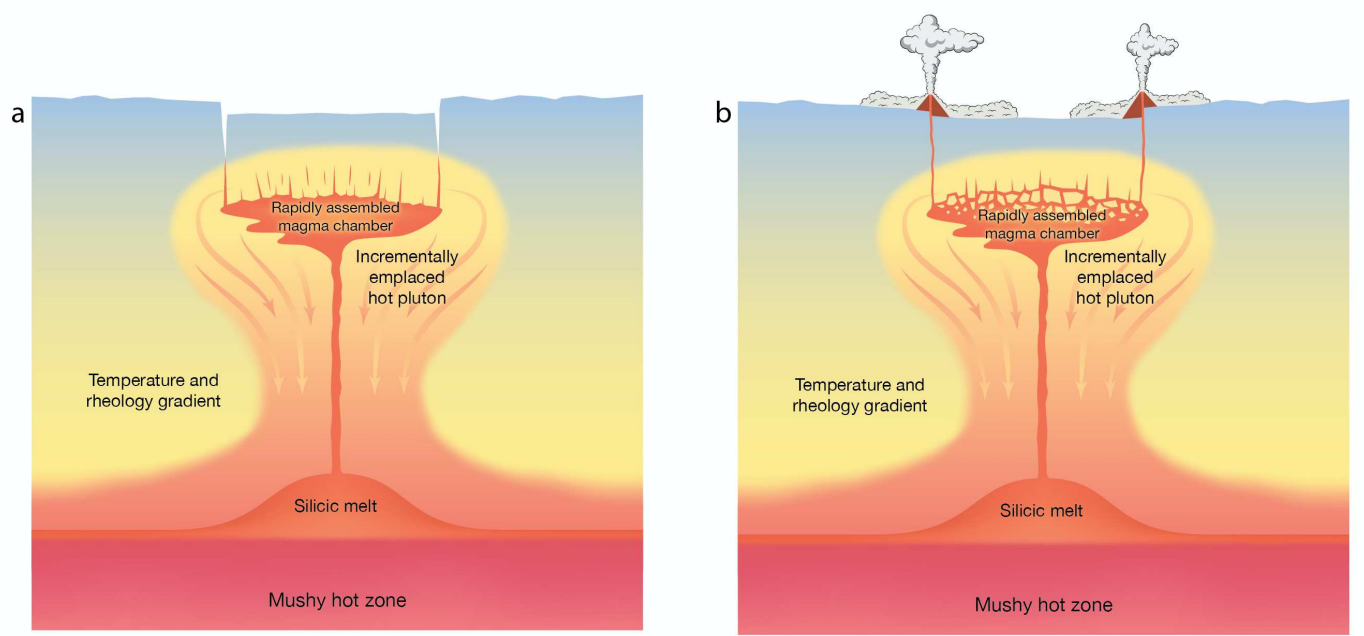

434

435 Figure 4. Simplified conceptual model of a transcrustal magmatic system involving 436 segregation of silicic melt from a middle to lower crustal hot zone, incipient Rayleigh Taylor 437 instability and transfer to an upper crustal magma chamber by a dyke. depiction is after the 438 incubation period in which a large batholith system has been emplaced in the upper crust and 439 hosts the development of the large magma chamber. In (a) the shallow magma chamber is 440 being emplaced prior to eruption and in (b) the surrounding co-genetic earlier plutonic rocks 441 are disrupted and incorporated into the erupting magma chamber.

442 
Magma system Terminology

447 A transcrustal igneous system spans the mantle to the surface and includes magma chambers, 448 igneous mush at or above the solidus and fully solidified cognate igneous rocks below the solidus, as well as host rocks consumed or intimately incorporated into the system by intrusive mechanisms. Mush is defined as a mixture of melt and crystals forming an interconnected framework in any proportions ${ }^{8}$, while magma is defined as melt regions containing suspended crystals. The transition between mush and magma occurs over crystal contents of typically $50-60 \%$. A magma reservoir is that part of the system containing melt. Mechanisms of forming large bodies of magma (chambers) ${ }^{8}$ include: incremental intrusion at flux rates sufficient to sustain high enough temperatures for magma formation ${ }^{14}$; segregation of evolved melts at the top of or within mushes ${ }^{19,21,48}$; amalgamation of smaller-scale meltrich layers within mushes to form larger-volume magma bodies ${ }^{23}$; reheating of mush or fully solidified igneous rocks ${ }^{49}$; and fluxing of higher-temperature fluids transferred from hotter mafic magmas ${ }^{50,51}$. Finally, super-eruptions are defined as eruptions of magnitude 8 or greater involving at least $10^{15} \mathrm{~kg}$ of magma ${ }^{52}$.

Geochronology

$463{ }^{40} \mathrm{Ar} /{ }^{39} \mathrm{Ar}$ ages were obtained from feldspar phenocrysts. Briefly, pyroclasts were crushed in a 464 jaw crusher, sieved, washed repeatedly in de-ionized water, before magnetically separated 465 to isolate feldspar phenocrysts. The feldspar phenocrysts were leached in an ultrasonic bath in $5 \% \mathrm{HF}$ for 5 minutes to remove adhering groundmass glass, before being rinsed three times 
in de-ionized water in an ultrasonic bath. Once dried, the feldspars were passed through a magnetic separator at low speed and low angle of tilt, to remove feldspar phenocrysts with mineral or melt inclusions. Samples were then hand-picked under a binocular microscope to eliminate any remaining crystals containing inclusions and any visibly altered crystals.

471 Sanidine crystals were harvested from individual pumice clasts and pumice fiamme from the

472 Cardones and Molinos ignimbrites to avoid contamination with accidental crystals picked up

473 from the conduit and surface during the eruption. This, however, was not possible for the 474 fine-grained Poconchile and Oxaya ignimbrites; we isolated sanidines from the bulk rock from 475 ignimbrites samples with very low lithic contents to minimize contamination. Many of the 476 sanidines from the Oxaya Formation are distinctively rich in Ba or have Ba-rich growth zones,

477 so we are confident that almost all the sanidines are cognate with the magmatic system, an 478 interpretation which was confirmed a posteriori. Our samples are typically $\sim 2 \mathrm{~mm}$ in 479 dimension but may be fragments of larger crystals as petrography indicated that sanidine 480 crystals up to $12 \mathrm{~mm}$ are common ${ }^{26} .50$ individual sanidine crystals from each ignimbrite for 481 laser fusion ${ }^{40} \mathrm{Ar}-{ }^{39} \mathrm{Ar}$ geochronology. Details of the samples and results are given in Table M1. 482 The data table for ${ }^{40} \mathrm{Ar}-{ }^{39} \mathrm{Ar}$ geochronology results (Table ED1) is in supplementary materials.

484 Pristine crystals were parcelled into Cu packets, or Al discs, stacked in glass vials and sealed in a large glass vial for irradiation. International standard Fish Canyon sanidine (FCs; with an age of $28.294 \pm 0.0036 \mathrm{Ma}$ ) were used as fluence monitors for J-determination and packaged throughout the stack at known spacing (geometry) in between samples. Samples and standards were irradiated at the Cd-lined (CLICIT) facility of the Oregon State University (USA) TRIGA reactor for 15.02 hours. Single irradiated crystals ( $n=30$ per sample) were fused with 

spectrometer ${ }^{52}$.

492

Samples were analyzed in a single batch; backgrounds and mass discrimination measurements (via automated analysis of multiple air pipettes) specific to each batch were used to correct the data. Air pipettes were run (on average) after every 4 analyses. Backgrounds subtracted from ion beam measurements were arithmetic averages and standard deviations. These were measured after every analysis. Mass discrimination was computed based on a power law relationship ${ }^{53}$ using the isotopic composition of atmospheric Ar reported by Lee et al. ${ }^{55}$ that has been independently confirmed ${ }^{56}$. Corrections for radioactive decay of ${ }^{39} \mathrm{Ar}$ and ${ }^{37} \mathrm{Ar}$ were made using published decay constants ${ }^{57,58}$.

501 Ingrowth of ${ }^{36} \mathrm{Ar}$ from decay of ${ }^{36} \mathrm{Cl}$ was corrected using the ${ }^{36} \mathrm{Cl} /{ }^{38} \mathrm{Cl}$ production ratio and methods of Renne et al. ${ }^{59}$ and was determined to be negligible.

504 The samples were analyzed by total fusion and step-heating with a $\mathrm{CO}_{2}$ laser. The mass spectrometer is equipped with a Nier-type ion source. The MAP 215-50 data were collected using an analogue electron multiplier detector. Mass spectrometry utilized peak-hopping by magnetic field switching for 10 cycles.

Ages were computed from the blank-, discrimination- and decay-corrected Ar isotope data

510 after correction for interfering isotopes based on the following production ratios, determined

511 from fluorite and Fe-doped $\mathrm{KAISiO}_{4}$ glass: $\left({ }^{36} \mathrm{Ar} /{ }^{37} \mathrm{Ar}\right)_{\mathrm{Ca}}=(2.650 \pm 0.022) \times 10^{-4} ;\left({ }^{38} \mathrm{Ar} /{ }^{37} \mathrm{Ar}\right)_{\mathrm{Ca}}=$

$512(1.96 \pm 0.08) \times 10^{-5} ;\left({ }^{39} \mathrm{Ar} /{ }^{37} \mathrm{Ar}\right)_{\mathrm{Ca}}=(6.95 \pm 0.09) \times 10^{-4} ;\left({ }^{40} \mathrm{Ar} /{ }^{39} \mathrm{Ar}\right)_{\mathrm{K}}=(7.3 \pm 0.9) \times 10^{-4}$ 
$513\left({ }^{38} \mathrm{Ar} /{ }^{39} \mathrm{Ar}\right)_{\mathrm{K}}=(1.215 \pm 0.003) \times 10^{-2} ;\left({ }^{37} \mathrm{Ar} /{ }^{39} \mathrm{Ar}\right)_{\mathrm{K}}=(2.24 \pm 0.16) \times 10^{-4}$, as determined

514 previously for this reactor in the same irradiation conditions ${ }^{60}$. Ages and their uncertainties

515 are based on the methods of Renne et al. ${ }^{61}$, the calibration of the decay constant ${ }^{62}$ and the

516 FCs optimization age. The optimization-modeled age has accurate quantifiable uncertainties

517 and hence is favored here over the astronomically tuned FCs ages ${ }^{63}$. The reason for this

518 preference is that the astronomical calibration has unknown uncertainty and confidence

519 intervals and uses best guess 'assumptions' to constrain, for example, phase relationships

520 between insolation and climate.

521

522 For the age comparisons made herein, contributions from sources of systematic uncertainty

523 (i.e., uncertainties in ${ }^{40} \mathrm{Ar} /{ }^{40} \mathrm{~K}$ of the standard and ${ }^{40} \mathrm{~K}$ decay constants) are neglected and only

524 analytical uncertainties in isotope measurements of samples and standards are included ${ }^{64}$.

525 These uncertainties are referred to herein as "analytical precision". For the purposes of this

526 study analytical uncertainties include contributions from uncertainties in the interference

527 corrections because these interference corrections have variable effects due to the slight

528 variable chemistry of the samples considered.

529

530 Zircon ages of three of the Oxaya ignimbrites have been previously presented ${ }^{25}$. These ages

531 were determined by single-crystal zircon U-Pb CA-ID-TIMS ${ }^{206} \mathrm{~Pb} /{ }^{238} \mathrm{U}$ analyses of high aspect

532 ratio zircons lacking any complex crystal shapes and evidence of older cores. Zircons with

533 inherited cores were excluded from the U-Pb ID-TIMS ${ }^{206} \mathrm{~Pb} /{ }^{238} \mathrm{U}$ analyses that contributed to

534 the estimates of eruption age. They were instead analysed by LA-ICPMS. These zircon crystals

535 are complex with resorbed cores. Ages determined by LA-ICPMS from inherited zircons 
536 (Figure 2) reveal highly dispersed age spectra (MSWD $>7$ for samples with $>50$ analyses, even

537 excluding antecrysts).

538

539 We investigated zircons from each unit that had been screened out from the single crystals

540 study eruptions age study. These excluded zircons included anhedral crystals with complex

541 shapes and zircons with cores. This population subset was analysed by LA-ICPMS U-Pb.

542 Zircons were analysed at the Geochronology \& Tracers Facility, British Geological Survey (GTF-

543 BGS) using a Nu Instruments, Nu Plasma HR, multi-collector inductively coupled plasma mass

544 spectrometer (MC-ICP-MS). The Nu Plasma HR was operated in static mode, with

545 simultaneous measurement of the isotopes of interest on either a Faraday detector or an ETP

546 secondary electron multiplier (see Table M2 below).

547

548

\begin{tabular}{|c|c||c|c|c|c|c|c|c||c|c|c|c|c|c|}
\hline ExH & H6 & H4 & H3 & H2 & H1 & Ax & L1 & L2 & IC0 & IC1 & L3 & IC2 & L4 & L5 \\
\hline${ }^{238} \mathrm{U}$ & ${ }^{235} \mathrm{U}$ & - & - & - & - & - & - & - & ${ }^{207} \mathrm{~Pb}$ & ${ }^{206} \mathrm{~Pb}$ & - & ${ }^{204} \mathrm{~Pb}$ & - & ${ }^{202} \mathrm{Hg}$ \\
& & \multicolumn{8}{|c|}{ Detectors not in use } & & & & & \\
\end{tabular}

549

550 Table M2: Configuration of the Nu Plasma HR 'Zircon' block used for U-Pb geochronology at

551 GTF-BGS. ${ }^{* 1}$ measured to allow for the correction of ${ }^{204} \mathrm{Hg}$ on ${ }^{204} \mathrm{~Pb}$. $\mathrm{H}$ denotes high mass

552 Faraday collectors, L denotes low mass Faraday collectors and IC denotes ion counter 553 detectors.

554

555 Laser sampling was performed using a New Wave Research 193nm laser ablation system,

556 incorporating an in-house designed, low-volume sample cell with an ablation volume of ca.

557 3-4 $\mathrm{cm}^{3}$, which, when combined with $\sim 1 \mathrm{~m}$ tubing to the plasma torch, leads to a signal

558 washout time of $\sim 1$ second. The ablation parameters were as follows: $35 \mu \mathrm{m}$ static spot, run 

with a 15 second washout/laser warm-up period between each analyses.

561

562 Data were acquired using the time-resolved analysis function of the Nu HR's software, and

563 processed using lolite; a software package specifically designed to handle the large volumes

564 of data produced by LA-ICP-MS. Lolite employs the 'standard-sample-bracketing' technique

565 to correct the data. This involves the calculation of a normalisation factor (measured/known)

566 for both the ${ }^{207} \mathrm{~Pb} /{ }^{206} \mathrm{~Pb}$ and ${ }^{206} \mathrm{~Pb} /{ }^{238} \mathrm{U}$ of a primary zircon reference material $(91500 ; 1062 \pm$

$5670.4 \mathrm{Ma}$ ), which is analysed at regular intervals during each session. These normalization

568 factors were then applied to the sample data. Two other zircon reference materials (GJ1 and

569 Mud Tank, $602 \pm 1$ Ma and $732 \pm 5 \mathrm{Ma}$, respectively) were also analysed during each session,

570 to check the accuracy and precision of this method.

571

572 Table ED2 in supplementary materials provides information on the individual ICP-MS zircon 573 analyses.

574

575 The propagated uncertainties were produced by lolite and reflect the quadratic combination

576 of the internal uncertainty, (i.e. the reproducibility of the measured ratios) with the external

577 uncertainty (i.e. the reproducibility of the bracketing reference material). Components

578 relating to the systematic uncertainty of the method (i.e. age uncertainty of the primary

579 reference material, decay constant uncertainties and the long-term variance of the secondary

580 reference material) are quadratically added, post lolite, using an in-house Excel spreadsheet. 
582 Dispersed ${ }^{40} \mathrm{Ar} /{ }^{39} \mathrm{Ar}$ and $\mathrm{U}-\mathrm{Pb}$ age distributions (Figure 2) preclude the calculation of a 583 traditional weighted mean, leading us to adopt a Bayesian approach to eruption age 584 estimation based on the algorithm of Keller et al. ${ }^{65}$. For either mineral, Bayesian eruption age 585 estimation requires a prior estimate of the relative age distribution of crystallization (zircon) or apparent closure (sanidine) ages prior to eruption, which may be estimated either

587 petrologically (e.g. zircon saturation modelling) or by bootstrapping ${ }^{66}$. Since the geological 588 process driving pre-eruptive age heterogeneity in sanidine is not yet well understood, we 589 must begin with a bootstrapping approach.

590

591 Incorporating all available ${ }^{40} \mathrm{Ar} /{ }^{39} \mathrm{Ar}$ age distributions that feature well-resolved pre-eruptive 592 heterogeneity, bootstrapping by kernel density estimation reveals (Figure S1) a consistent, 593 exponential form of the relative closure age distribution. This exponential form suggests an underlying survivorship process (e.g. potentially consistent with geologic processes ranging from partial degassing of xenocrystic sanidine entrained during eruption to pre-eruptive $\mathrm{Ar}$ accumulated in a cold-storage regime. We note that for excess $\mathrm{Ar}$ a continuum of ages as observed would not be expected. When cast on an isotope correlation plot, the Ar/Ar data define isochrons with atmospheric ${ }^{40} \mathrm{Ar} /{ }^{36} \mathrm{Ar}$, albeit at relatively low precision owing to the high radiogenic Ar content. Using this bootstrapped relative closure age distribution, the resulting eruption age estimates based on ${ }^{40} \mathrm{Ar} /{ }^{39} \mathrm{Ar}$ sanidine ages for the Cardones are 601 indistinguishable within uncertainty from those based on U-Pb CA-ID-TIMS zircon 602 crystallization ages (Table MD1), whereas the ${ }^{40} \mathrm{Ar} /{ }^{39} \mathrm{Ar}$ sanidine ages for Poconchile and

603 Oxaya ignimbrites are just beyond uncertainty of each other. To account for this we calculate 604 an integrated ${ }^{40} \mathrm{Ar} /{ }^{39} \mathrm{Ar}$ and U-Pb age. 
606 We re-calculated the previous zircon ages ${ }^{25}$ using the Bayesian method. Incorporating 607 constraints from both sanidine and zircon eruption age estimates, we also estimate the 608 repose intervals between eruptions as illustrated in Figure S2, using the superposition 609 algorithm of Keller ${ }^{54}$.

610

611 We first estimated empirically the form of the relative closure distribution, analagous to 612 the relative crystallization distribution of Keller et al. ${ }^{66}$ using a method equivalent to the 613 "boostrapping" approach ${ }^{67}$. The results (Figure S1) revealed a characteristic form of the

614 closure distribution featuring a nearly exponential decrease in probability density with 615 increasing time prior to eruption. The consistency and reproducibility of this form, to first 616 order, between all available well-resolved single-crystal volcanic sanidine Ar-Ar age 617 distributions (both from the Andean ignimbrites of this study, and the Mesa Falls Tuff ${ }^{67}$ ) 618 suggests that this exponential form may be underlain by a consistent physical process. A 619 survivorship process wherein, for example, each sanidine has some finite probability of being 620 reset by reheating in any given pre-eruptive time interval - would provide one simple 621 mechanism for producing such an exponential trend.

622

623 We then applied the Markov chain Monte Carlo eruption age estimation algorithm in the 624 Chron.jl software package ${ }^{65}$ to each ignimbrite, using a half-Normal relative crystallization 625 distribution for all ID-TIMS zircon ages, and our previously determined exponential relative 626 closure distribution for all sanidine $\mathrm{Ar}-\mathrm{Ar}$ ages, as illustrated in Figure S2. Systematic 627 uncertainties were propagated using the "optimization intercalibration" the constants of 628 Renne et al. ${ }^{62}$ for Ar-Ar ages, and the decay constants of Jaffey et al. ${ }^{68}$ along with the effective 629 systematic uncertainty of the EarthTime tracer ${ }^{69,70}$ for U-Pb TIMS ages. Finally, to estimate 

the durations of the repose intervals between each ignimbrite (Figure S2), we used Chron.jl

631 to run a second "stratigraphic" MCMC model, combining both the new eruption age estimates and the relative age constraints provided by the stratigraphic superposition of the 633 ignimbrites. Table M1 shows all model outputs.

\section{Diffusion modeling}

637 Argon diffusion calculations were carried out using analytical solutions for simultaneous 638 production and diffusion ${ }^{71,72}$. These solutions, which involve two infinite series, typically converge with less than 20 partial sums. We use measured argon diffusion kinetics for Fish

640 Canyon sanidine ${ }^{73}$. We assume that all sanidine crystals form at $26.5 \mathrm{Ma}$, reside at a constant temperature until 21.8 Ma (the approximate eruption age of Cardones) and experience no no argon diffusion occurs during cold storage (i.e., that ${ }^{40} \mathrm{Ar}$ concentration profiles in sanidine crystals were uniform at the beginning of magma residence). Because some prior diffusive rounding of the ${ }^{40} \mathrm{Ar}$ concentration profiles likely occurred during cold storage, our estimates of magma residence times should be considered minima.

648 Uncertainties in cold storage temperatures due to uncertainties in argon diffusion kinetics are

649 fairly invariant and range from \pm 5 to $\pm 6 \stackrel{\circ}{ } \mathrm{C}(1 \sigma)$, with the largest uncertainties corresponding 650 to small grain sizes and low degrees of fractional argon loss (i.e., older ${ }^{40} \mathrm{Ar} /{ }^{39} \mathrm{Ar}$ ages). Because

651 magma residence times range over a few orders of magnitude, absolute uncertainties in magma residence times due to uncertainties in argon diffusion kinetics also range over a few 
orders of magnitude. Generally, magma residence time uncertainty increase with increasing

654 and degree of fractional argon loss (i.e., younger ${ }^{40} \mathrm{Ar} /{ }^{39} \mathrm{Ar}$ ages), increasing grain size, and decreasing magma residence temperature. Relative uncertainties in magma residence times, on the other hand, are essentially invariant with grain size or degree of fractional loss, and

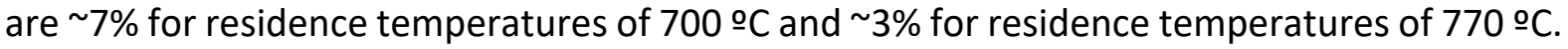
For example, for an $11 \mathrm{~mm}$-diameter sanidine grain that experienced $96 \%$ fractional loss (i.e., has an ${ }^{40} \mathrm{Ar} /{ }^{39} \mathrm{Ar}$ age of $22 \mathrm{Ma}$ ), the residence time at $700{ }^{\circ} \mathrm{C}$ is $356 \pm 25$ years, while the residence time at $770{ }^{\circ} \mathrm{C}$ is $57 \pm 2$ years.

661

662

\section{Magma transport modelling}

663

664

665

666

667

668

669

670

671 where $\dot{h}$ is the growth rate of the unstable layer, $\mathrm{g}$ is gravity, $\Delta \rho$ is the density difference

We apply here an experimentally verified model for the development of buoyancy induced instability for a growing melt layer beneath a layer of much greater viscosity ${ }^{22}$. Here a silicic melt layer extracted from an underlying mush accumulates beneath hot upper crust (Figure 4). The wavelength of the fastest growing RT instability in the case of an unconfined layer is given by;

672 between melt and overlying crust, $\mu_{m}$ is the viscosity of the silicic melt layer, and $\mu_{\mathrm{c}}$ is the

673 viscosity of overlying hot just sub-solidus crust. Representative values are $\Delta \rho=300 \mathrm{~kg} / \mathrm{m}^{3}, \mu_{\mathrm{m}}$ $674=10^{5} \mathrm{~Pa} \mathrm{~s}$, and $\mu_{\mathrm{c}}=10^{19} \mathrm{~Pa} \mathrm{~s}^{42}$. We take $\dot{h}$ values of $1 \mathrm{~mm}$ and $5 \mathrm{~mm} /$ year based on models 675 of reactive flow related to basalt underplating ${ }^{20}$ resulting in $\lambda$ values of 600 and $1400 \mathrm{~km}$. 
676 Although approximate these calculations show that the fastest growing wavelength is much

677 larger than the width of zones of magma generation beneath batholiths, taken here to be 678 typically in the range 30 to $50 \mathrm{~km}$. Thus we have applied the theory for confined instability 679 growth ${ }^{21}$ for $\mu_{\mathrm{m}}<<\mu_{\mathrm{c}}$ to calculate a characteristic time scales for instability:

680

681

$$
\tau=\left(6 \pi \mu_{c}\right) /(\Delta \rho g D)
$$

682

683

During experiments described in Seropian et al. ${ }^{22}$ we observed from 16 experiments covering

684

a wide range of material properties (analogue melt layer thicknesses, $\mu_{c}$ and $\Delta \rho$ ) that the time 685 it takes an instability to transform into a detached diapir was about 4 greater than $\tau$, leading 686 to equation (1) in the main text.

687

One possibility is that the RT instability grows to form a diapir which traverses the intervening 689 plutonic crust. However, magma transport by diapirism is too slow to explain the rapid assembly of magma chambers prior to ignimbrite eruptions: we estimate using equation 8 in Burov et al. ${ }^{45}$ that a $1000 \mathrm{~km}^{3}$ diapir with $\Delta \rho=300 \mathrm{~kg} / \mathrm{m}^{3}$ takes $\sim 10^{5}$ years to rise $10 \mathrm{~km}$ in a crust with an effective viscosity of $10^{19} \mathrm{~Pa}$ s. This simplified calculation does not consider heat loss from the diapir, which locally reduces the viscosity of the surroundings ${ }^{44}$, which in turn enables somewhat faster ascent and could help assimilate older plutonic material into the diapir as it ascends. Although this mechanism could explain the spectrum of zircon ages it is not consistent with the abundant old sanidines. Thus dyke transport ${ }^{46}$ provides an attractive mechanism to enable fast magma chamber assembly. 
In our conceptual model (Figure 4) a conduit (dyke or cylinder) is formed that allows an

700

701

702

703

704

705

706

707

708

709

710

711

712

713

714

715

716

717

718

719

720

721

722

exchange flow ${ }^{47}$ between the middle crustal melt layer and an upper crustal region in which a magma chamber forms. Here we envisage that upward flow of magma along the conduit is balanced by the downward subsidence of the crust. We are interested in the case where the cross-sectional area of the magma conduit is much less than the area of crust flowing downwards $\left(A_{m}<<A_{c}\right)$ and the magma is much less viscous than the crust $\left(\mu_{m}<<\mu_{c}\right)$. In this scenario the average speed of the crust downward $\left(U_{c}\right)$ is less than the average magma flow speed up the conduit: $U_{c} \approx\left(A_{m} / A_{c}\right) U_{m}$ by many orders of magnitude. To develop a very simple model we represent the subsiding crust as a large cylinder of radius $\mathrm{R}$ and the conduit as a small cylinder of radius $r$; note that for a dyke with a length 1000 times its width, its width is approximately a quarter of the radius $r$ of a cylindrical conduit that would accommodate the same flux. Due to the low crust velocity and the large viscosity contrast, the upward flow of magma is well approximated by flow through a cylinder with solid walls (Poiseuille flow):

where $Q$ is the magma flux (volume/time) through the conduit. Approximating the downward flow as Poiseuille flow with radius $R$ also with flux $Q$, results in the following relationship:

We have applied equations to make the calculations presented in Table 1 . We note that the difference between an exchange flow along a cylinder and a dyke is a matter of geometry with viscous friction being a factor of a few greater in a dyke with the same cross-sectional 
area as a cylinder. The length of the dyke is an additional factor in governing friction and

different choices could be made, but would have a minor effect on calculated magma fluxes.

Thus the essential elements of exchange flow are captured by a cylindrical conduit. Even for

a cylindrical geometry the calculations presented are approximate and intended only to

727 illustrate the feasibility of the crust subsiding slowly over a large area allowing an exchange flow with relatively fast ascent of magma from the mid- to the upper crust.

Methods References

731

732

48. Jackson, M. D., Cheadle, M. J. \& Atherton, M. P. Quantitative modeling of granitic melt generation and segregation in the continental crust. Journal of Geophysical Research 108, 2332-2353(2003).

735

49. Huppert, H.E. \& Sparks, R.S.J. The generation of granite by intrusion of basalt into the continental crust. Journal of Petrology 29, 599-624 (1988).

50. Bachmann, O. \& Bergantz, G. W. Gas percolation in upper crustal silicic crystal mushes as a mechanism for upward heat advection and rejuvenation of near-solidus magma bodies. Journal of Volcanology and Geothermal Research 149, 85-102 (2006).

740 51. Huber, C., Bachmann, O. \& Manga, M. Two Competing Effects of Volatiles on Heat

741 Transfer in Crystal-rich Magmas: Thermal Insulation vs Defrosting. Journal of Petrology 51, $742 \quad 847-867(2010)$.

743 52. Mason, B., Pyle, D. \& Oppenheimer, C. The size and frequency of the largest explosive 744 eruptions on earth. Bulletin of Volcanology 66, 735-748 (2004).

745 53. Mark, D.F., Petraglia, M., V.C. Smith, Morgan, L.E., Barfod, D.N., Ellis, B.S. N.J.Pearce, 
747 of ultra-distal tephra: forcing of Quaternary climate and implications for hominin occupation

748 of India. Quaternary Geochronology 21, 90-103 (2014).

749 54. Renne, P.R. Cassata, W.S. \& Morgan, L.E. The isotopic composition of atmospheric 750 argon and 40Ar/39Ar geochronology: time for a change? Quaternary Geochronology 4, 288751298 (2009).

752 55. Lee, J.Y. Marti, K., J.P. Severinghaus, J.P., Kawamura, K., Yoo, H.S., Lee, J.B. \& Kim, J.S.

753 A redetermination of the isotopic abundances of atmospheric Ar

754 Geochimica et Cosmochimica Acta 70, 4507-4512 (2006)

755 56. D.F. Mark, D.F., Stuart, F.M., \& de Podesta, M. New high-precision measurements of 756 the isotopic composition of atmospheric argon. Geochimica et Cosmochimica Acta 75, 7494$7577501(2011)$

758 57. Stoenner, R.W., Schaeffer, O.A. \& Katcoff, S. Half-lives of argon-37, argon-39, and 759 argon-42. Science 148, 1325- 132 (1965).

760 58. Renne, P.R. \& Norman, E.B. Determination of the half-life of 37Ar by mass 761 spectrometry. Physics Reviews C 63, 047302 (2001).

762 59. Renne, P.R., Sharp, Z.D. \& Heizler, M.T. Cl-derived argon isotope production in the 763 CLICIT facility of OSTR reactor and the effects of the Cl-correction in 40Ar/39Ar 764 geochronology. Chemical Geology 255. 463-466 (2008).

765 60. Renne P.R. Some footnotes to the optimization-based calibration of the 40Ar/39Ar 766 system. Geological Society London Special Publication 378, 21-31 (2014).

767 61. Renne, P.R., Mundil, R., Balco, G., Min, K. \& Ludwig , K.R. Joint determination of 40K 768 decay constants and $40 \mathrm{Ar} * / 40 \mathrm{~K}$ for the Fish Canyon sanidine standard, and improved 769 accuracy for 40Ar/39Ar geochronology. Geochimica et Cosmochimica. Acta 74, 5349-5367 770 (2010). 
62. Renne, P.R., Mundil, R., Balco, G., Min, K., Ludwig K.R. Response to the comment by

W. H. Schwarz et al. on "Joint determination of $40 \mathrm{~K}$ decay constants and $40 \mathrm{Ar} * / 40 \mathrm{~K}$ for the

Fish Canyon sanidine standard, and improved accuracy for 40Ar/39Ar geochronology.

Geochimica et Cosmochimica Acta 75, 5097-5100 (2011).

63. Kuiper, K.F., Deino, A., F.J. Hilgen, F.J., Krijgsman, Renne, P.R. \& Wijbrans, J.R. Synchronizing rock clocks of Earth history. Science 320, 500-504 (2008).

64. Mark, D.F., Renne, P.R. Dymock, R.C., Smith, V.C., Simon, J.I., Morgan, L.E. Saff, R.A.,

Ellis, B.S. \& Pearce, N.J.G. High precision 40Ar/39Ar dating of Pleistocene tuffs and temporal anchoring of the Matuyama-Brunhes Boundary. Quaternary Geochronology 39, 1-23 (2017).

65. Keller, C.B. Chron.jl: A Bayesian framework for integrated eruption age and age-depth modelling. https://doi.org/10.17605/osf.io/TQX3F (2018).

782

66. Keller, C. B., Schoene, B. \& Samperton, K. M. A stochastic sampling approach to zircon eruption age interpretation. Geochemical Perspectives Letters 8, 31-35 (2018).

67. Ellis, B.S., Mark, D.F., Troch J., Bachmann, O., Guillong, M, Kent, A.J.R. \& von Quadt, A. Split-grain 40Ar/39Ar dating: Integrating temporal and geochemical data from crystal cargoes. Chemical Geology 457, 15-23 (2017).

787

68. Jaffey, A.H., Flynn, K.F., Glendenin, L.E., Bentley, W.C. \& Essling, A.M. Precision Measurement of Half-Lives and Specific Activities of $235 \mathrm{U}$ and 238U. Physics Reviews C 4, 1889 (1971).

69. Condon, D.J., Schoene, B., McLean, N.M., Bowring, S.A. \& Parrish, R.R. Metrology and traceability of $\mathrm{U}-\mathrm{Pb}$ isotope dilution geochronology (EARTHTIME Tracer Calibration Part I). Geochimica et Cosmochimica Acta 164, 464-480 (2015).

70. McLean, N.M. , Condon D.J., Schoene, B. \& Bowring, S.A. Evaluating uncertainties in 794 the calibration of isotopic reference materials and multi-element isotopic tracers 
795 (EARTHTIME Tracer Calibration Part II). Geochimica et Cosmochimica Acta 164, 481-502 796 (2015).

797 71. Wolf, R. A., Farley, K. A. \& Kass, D. M. Modeling of the temperature sensitivity of the 798 apatite (U-Th)/He thermochronometer. Chemical Geology 148, 105-114 (1998).

799 72. McDougall, I., \& Harrison, T. M. Geochronology and Thermochronology by the 800 40Ar/39Ar Method. (Oxford University Press on Demand, 1999).

801 73. Cassata, W. S. \& Renne, P. R. Systematic variations of argon diffusion in feldspars and 802 implications for thermochronometry. Geochimica et Cosmochimica Acta 112, 251-287 803 (2013).

804

805 Acknowledgements

806 This project was funded by BHP supporting the PhD of Marit van Zalinge. BHP have given 807 permission to publish. Zircon and sanidine analyses were supported by Natural Environment 808 Research Council Isotope Geosciences Facilities Steering Committee grant IP-1466-1114 and 809 Royal Society Research Grant RG140683 to FJC. Dan Condon is thanked for his help with the 810 analyses of inherited zircons. NERC are thanked for ongoing funding of the National 811 Environmental Isotope Facility. RSJS acknowledges support of a Leverhulme Trust Emeritus 812 Fellowship.

814 Author contributions.

815 Van Zalinge carried out field work, collected the samples and prepared them for 816 geochronological analyses. Mark conducted the ${ }^{40} \mathrm{Ar} /{ }^{39} \mathrm{Ar}$ analyses at the East Kilbride 817 laboratories. Keller and Mark applied a Bayesian model to interpret the geochronological 818 data. Mark and Sparks integrated and interpreted the geochronology and developed the 
819 scientific narrative. Tremblay contributed argon diffusion modeling to estimate storage 820 temperatures and magma residence times for sanidine crystals. Rust analysed RT experiment

821 data for the diapir detachment timescale. Rust and Sparks developed the exchange flow 822 models for magma transport. Sparks and Mark led drafting the article and all authors 823 contributed to the writing. Cooper and Sparks supervised PhD student Van Zalinge.

824 


\section{Supplementary Files}

This is a list of supplementary files associated with this preprint. Click to download.

- TableED1.ArArdatasummary.xlsx

- TableED2.UPbLAICPMSdatasummary.xIsx

- SupplementaryMaterialsfigureandsampletable.pdf 